\title{
THE PREVALENCE OF HEPATITIS C VIRUS INFECTION AND POTENTIAL RISK FACTORS AMONG MULTIPLY TRANSFUSED PATIENTS
}

\author{
MANAL KHUDDER ABDUL RAZAK* \\ Department of Medicine, Baghdad College of Medicine, University of Baghdad, Bab Al-Muadham Campus, Baghdad Iraq. \\ Email: manaladhadh@gmail.com
}

Received: 5 September 2018, Revised and Accepted: 26 November 2018

\section{ABSTRACT}

Objective: Patients who frequently receive blood have high risk of hepatitis C virus (HCV) infection. This study aimed to evaluate the prevalence of $\mathrm{HCV}$ infection and potential risk factors among multiply transfused patients.

Methods: A cross-sectional retrospective study was conducted in the hemophilia unit in Medical City in Baghdad, between June 1, 2016, and January 1, 2017. After taking consents and approval of ethical comity, the medical records of 1158 patients with hemophilia A and B, von Willebrand disease (vWD), thrombasthenia, Factors VII, X, and XIII deficiencies, and hypofibrinogenemia were analyzed for the presence of HCV antibody using (enzyme-linked immunosorbent assay). Cases of hemophilia were classified into mild, moderate, and severe.

Results: The prevalence of HCV infection was 13.2\%. Of total, 595 (51.4\%) patients had hemophilia A and 99 (16.6\%) were anti-HCV positive, while 225 (19.4\%) had hemophilia B and 28 (12.4\%) were antibody positive compared to 9 (7\%) in vWD. Of those with hemophilia A, 515 (86.6\%) had severe hemophilia, and 32 (32.32\%) cases had acquired HCV infection after 1996 (after introduction of HCV screening in blood banks in Iraq). There was a statistically significant association with treatment by Factor VIII only.

Conclusion: The prevalence of HCV in patients with inherited bleeding disorder is $13.2 \%$. In this study, it was found that multitransfusion is the only predictor for HCV infection in this group of patients.

Keywords: Hepatitis C virus, Multitransfusion, Prevalence.

(C) 2019 The Authors. Published by Innovare Academic Sciences Pvt Ltd. This is an open access article under the CC BY license (http://creativecommons. org/licenses/by/4. 0/) DOI: http://dx.doi.org/10.22159/ajpcr.2019.v12i1.29515

\section{INTRODUCTION}

Hepatitis C virus (HCV) infection is considered as an important health problem, worldwide. It is the most important cause of morbidity and mortality in multiply transfused patients due to inherited bleeding disorders $[1,2]$. Most asymptomatic blood donors were found to have anti-HCV antibodies and about $20-30 \%$ of persons with reported cases of acute hepatitis C do recall risk- associated behaviors when questioned carefully [3].

Evidence indicated that the risk of acquisition of HCV infection is higher in hemophiliacs than patients with other inherited bleeding disorders. In most studies, $80-100 \%$ of patients remain HCV (RNA) positive, and $60-80 \%$ have persistently elevated liver enzymes [4]. Unfortunately, HCV successfully evades the host immune response in $55-85 \%$ of acutely infected persons, thus leading to chronic infection which can lead to cirrhosis and hepatocellular carcinoma $[5,6]$.

Early diagnosis and treatment of HCV infection among patients with inherited bleeding disorders is required because the response to treatment reduces with age [7].

This study aimed to evaluate the prevalence of HCV infection and determine potential risk factors among multiply transfused patients.

\section{METHODS}

\section{Study design}

This is a cross-sectional retrospective study carried out in the hemophilia unit in Children Welfare Teaching Hospital, Medical City in Baghdad/Iraq, during a period between June 1, 2016, and January 1, 2017. This study involved all patients with inherited bleeding disorders including hemophilia $\mathrm{A}$ and $\mathrm{B}$, von Willebrand disease (vWD), thrombasthenia, hypofibrinogenemia, and deficiency of factors (VII, X, and XIII); of all ages who were registered in this ward. Demographic and virological data from 1158 patients were surveyed and analyzed. Testing for HCV antibody using enzyme-linked immunosorbent assay (ELISA) test (third generation) was performed in the local hospital laboratories at baseline and every 6 months. Hence, those test results were extracted from patient records. The level of severity of hemophilia A was determined depending on the amount of clotting factor that is missing from a person's blood as shown in Table 1 .

Hemophiliacs were classified into mild, moderate, and severe cases accordingly [8]. In general, hemophiliacs were treated with FVIII and FIX concentrates alone or with factor, blood products, and whole blood. Patients after being diagnosed with HCV infection were referred to the gastrointestinal center for further management.

\section{Statistical analysis}

Minitab 17 program package was used to analyze the data, AndersonDarling test was used to test normality of data. Median of data and interquartile range (IQR) were used to describe the data. A non-parametric method was used to assess the statistical significance between variables, Kruskal-Wallis test was used to test the equality of medians for two or more variables, while Mann-Whitney U-test was used to test the equality of two population medians, and calculate the corresponding p-value. Data were presented using bar when presenting prevalence. All data were considered significant when ${ }^{*} \mathrm{p}<0.05$ and highly significant when ${ }^{* *} \mathrm{p}<0.001$.

\section{RESULTS}

Medical records of 1158 patients with inherited bleeding disorders were analyzed. Of total, 153 patients were HCV antibody positive with a prevalence of $13.2 \%$ as shown in Fig. 1. 
Table 1: Hemophilia A severity

\begin{tabular}{lll}
\hline Level & Percentage of normal factor VIII activity in blood (\%) & Number of IUs per milliliter (ml) of whole blood \\
\hline Normal range & $50-150$ & $0.50-1.5 \mathrm{IU}$ \\
Mild hemophilia & $5-40$ & $0.05-0.40 \mathrm{IU}$ \\
Moderate hemophilia & $1-5$ & $0.01-0.05 \mathrm{IU}$ \\
Severe hemophilia & $<1$ & $<0.01 \mathrm{IU}$ \\
\hline
\end{tabular}

IUs: International units

Table 2: The frequency of HCV infection among the study group

\begin{tabular}{lll}
\hline Variables & All patients number (\%) & HCV number (\%) \\
\hline Hemophilia A & $595(51.4)$ & $99(64.7)$ \\
Hemophilia B & $225(19.4)$ & $28(18.3)$ \\
vWD & $128(11.1)$ & $9(5.9)$ \\
Thrombasthenia & $100(8.6)$ & $2(1.3)$ \\
Factor VII deficiency & $35(3.0)$ & $5(3.3)$ \\
Factor XIII deficiency & $34(2.9)$ & $2(1.3)$ \\
Hypofibrinogenemia & $32(2.8)$ & $4(2.6)$ \\
Factor X deficiency & $9(0.8)$ & $4(2.6)$ \\
Total & $1158(100)$ & $153(100)$ \\
\hline
\end{tabular}

vWD: Von Willebrand disease, HCV: Hepatitis C virus

As shown in Table 2, 595 (51.4\%) were cases with hemophilia A, 225 (19.4\%) with hemophilia B, and 128 (11.1\%) with vWD. Of 153 patients who were infected with HCV, $64.7 \%$ were cases of hemophilia A and 28 (18.3\%) of hemophilia B.

The prevalence of $\mathrm{HCV}$ infection was $16.6 \%$ in hemophilia A, $12.4 \%$ in hemophilia B, and 7\% in vWD, as shown in Fig. 2.

Since most of the data did not follow normal distribution, nonparametric methods were used to assess the variation in median of data. Median and IQR were selected to present the data. Median age (IQR) of patients having hemophilia B, hemophilia A, and vWD was 31 (10.5), 24 (11.5), 19 (23), respectively. Median age at the diagnosis of HCV of the patients with hemophilia A, B, and vWD was almost the same (10 years) as shown in Table 3 .

Of all patients with hemophilia A with hepatitis, 515 (86.6\%) patients showed severe Factor VIII deficiency while 80 (13.4\%) patients had moderate deficiency. Of those with hemophilia B with hepatitis, 201 (89.3\%) showed severe Factor VIII deficiency while 24 (10.71\%) patients had moderate deficiency without a statistically significant difference $(p=1)$.

Factor VIII inhibitors were found in 116 (19.6\%) of the cases of hemophilia A while none of the cases of hemophilia B showed positive to Factor IX with a statistically highly significant difference $(\mathrm{p}<0.001)$.

Studying the effect of treatment type (Factor VIII + blood product vs. factor only), and age at diagnosis of hemophilia A on infection with $\mathrm{HCV}$, showed a relationship between type of treatment and development of infection with HCV when holding age at diagnosis constant with a statistically significant difference $(\mathrm{p}=0.03)$, while age did not display such relationship. For patients who were treated with blood product and factors, the negative coefficient of -1.43 and the odds ratio (OR) of 0.24 indicate that those subjects tend to have a higher HCV infection rate than subjects who were treated with factors only. Given that, subjects have the same age at diagnosis of hemophilia A, the OR can be interpreted as the odds of patients taking blood products having no infection with HCV being $24 \%$ of the odds of patients taking only factors having no HCV infection as shown in Table 4.

As shown in Table 5, treatment type did not affect the number of years to get HCV infection from time of the diagnosis of hemophilia A, while age at diagnosis of hemophilia showed a statistically significant effect. The negative coefficient and an $\mathrm{OR}<1$ indicate that as hemophilia

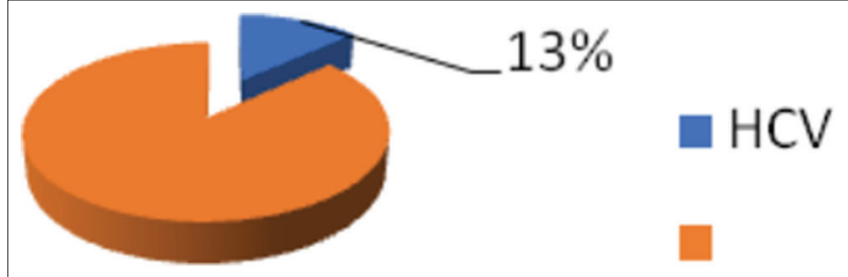

Fig. 1: Prevalence of hepatitis $C$ virus infection in inherited coagulopathy

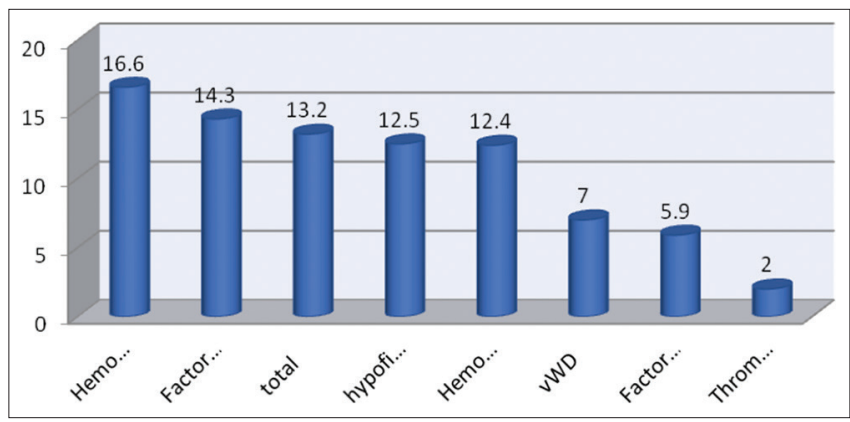

Fig. 2: The prevalence of hepatitis $C$ virus infection in the study group

A patients diagnosed younger the highest the possibility to get HCV infection when holding the effect of treatment type constant.

As shown in Table 6, 32 (32. 32\%) cases of hemophilia A who were HCV positive had acquired HCV infection after 1996, it means after the introduction of screening for HCV in blood donors in Iraq.

Only patients with hemophilia A show a statistically significant association between the period of the diagnosis of HCV infection whether before or after 1996 and treatment received, the value of correlation coefficient $(0.375)$ as shown in Table 7.

\section{DISCUSSION}

In the present study, 127 (15.48\%) hemophiliacs (type A and B) had antibody to HCV. Various studies among multiply transfused hemophilia patients demonstrated a wide range of prevalence of the transfusiontransmitted infections. The prevalence of HCV infection in Iran ranged between $29 \%$ and $83.3 \%$ in different cities or province of Iran. The lowest rate was in Zahedan and the highest in Tehran [4,9-11]. The rate of HCV infection in one study in Taiwan was $45.7 \%$ [12]. It was lower in Pakistan (36\%) [13].

In the Netherlands, it was found to be $68 \%$ [14]. Studies from some neighboring Arabic countries reported an HCV infection rate of 78.6\% among multitransfused patients $[15,16]$. A study done in Egypt showed that HCV prevalence among multitransfused patients ranged between $10 \%$ and $55 \%$ [17].

Although patients with thalassemia were not included in this study, it is wise to mention that the prevalence of HCV in a study in India was $18.70 \%$ (320 of 1711 patients with thalassemia) [18]. 
Table 3: Distribution of patient's characteristics

\begin{tabular}{lllll}
\hline Variables & Hemophilia A & Hemophilia B & vWD'disease & p \\
\hline Current age/year median (IQR) & $24(11.5)$ & $31(10.5)$ & $19(23)$ & 0.065 \\
Age/year at Dx. of HCV median (IQR) & $10(6.5)$ & $9(7.8)$ & $10(11)$ & 0.098 \\
Severe deficiency (VIII)/number (\%) & $515(86.6)$ & $201(89.3)$ & - & 1 \\
Moderate deficiency (VIII)/number (\%) & $80(13.4)$ & $24(10.71)$ & - & $<0.001^{* *}$ \\
VIII inhibitor (\%) & $116(19.6)$ & - & - & \\
IX inhibitor & - & 0 & - & \\
\hline
\end{tabular}

"Von Willebrand disease, **Highly significant difference. vWD: Von Willebrand disease, IQR: Interquartile range, HCV: Hepatitis C virus

Table 4: Binary log regression of treatment type versus age at diagnosis of hemophilia A and infection with HCV

\begin{tabular}{llll}
\hline Predictor & Correlation coefficient & $\mathbf{p}$ & $\mathbf{O R}^{* *}$ \\
\hline Treatment* $^{*}$ & -1.43 & 0.03 & 0.24 \\
Age at diagnosis & -0.005 & 0.971 & 0.99 \\
\hline
\end{tabular}

Treatment*: Factor+blood product versus factors only. OR**: Odds ratio,

HCV: Hepatitis C virus

Table 5: Ordinal log regression of duration in years from diagnosis of hemophilia $\mathrm{A}$ to diagnosis of $\mathrm{HCV}$ versus treatment type and age at diagnosis of hemophilia $A$

\begin{tabular}{llll}
\hline Predictor & Correlation coefficient & $\mathbf{p}$ & $\mathbf{O R}^{* *}$ \\
\hline Treatment* & 0.29 & 0.433 & 1.34 \\
Age at diagnosis of & -0.26 & 0.024 & 0.77 \\
hemophilia A & & & \\
\hline
\end{tabular}

Treatment*: Factor+blood product versus factors only. OR**: Odds ratio, HCV: Hepatitis C virus

Table 6: Distribution of the cases of hemophilia A and $B$ and patients with vWD according to the period of positivity of HCV (before or after 1996)

\begin{tabular}{ll}
\hline Variable & Count (\%) \\
\hline Hemophilia A & \\
Before 1996 & $67(67.68)$ \\
After 1996 & $32(32.32)$ \\
Hemophilia B & \\
$\quad$ Before 1996 & $24(85.71)$ \\
After 1996 & $4(14.29)$ \\
vWD* & $2(22.22)$ \\
Before 1996 & $7(77.78)$ \\
After 1996 &
\end{tabular}

Other studies showed lower rates of HCV infection. Central and East Asia and North Africa/Middle East are estimated to have a prevalence ( $>3.5 \%, 3.5 \%)$, whereas Asia Pacific, Tropical Latin America, and North America have very low prevalence $(<1.5 \%)$ [19]. The difference observed in different populations may be due to laboratory methods and selection methods.

In the present study, the overall prevalence of HCV infection among cases of inherited coagulopathy was $13.2 \%$ which is considered very high because in Iraq hepatitis $\mathrm{C}$ is considered of low endemicity with a rate of $0.5 \%$ in blood donors $[20,21]$ compared with other countries. In studies reporting HCV prevalence among hemophiliacs in the Maghreb countries, the highest prevalence was reported in Libya 94\%, while it was $30 \%$ in Algeria, and was $42 \%$ in Morocco [22].

This difference in the prevalence of HCV infection attributed to different epidemiological distribution and risk factors of HCV infection between these countries. The prevalence of HCV infection in blood donors in another study done in Iraq (Baghdad) between 2006 and 2009 was found to be $0.3 \%$ in all donors [23]. This indicates that blood product is important predisposing factor to get HCV infection despite the extensive screening and disinfection procedure done in our country. This could be attributed to the fact that multiple use of the same person over time to blood products in their life leads to that increased cumulative risk to get HCV infection as shown by Yazdani et al. who found that only multitransfusion is independently associated with HCV infection [11].

In Iraq, anti-HCV ELISA (third generation) is the only screening test for the detection of $\mathrm{HCV}$ infection in all blood donors. After exposure to HCV, anti-HCV antibodies can be detected by ELISA in $50-70 \%$ of the patients at the onset of symptoms, this percentage increased to approximately $90 \%$ after 3 months and the remaining $10 \%$ may take even longer, despite the presence of viremia in acute infections [24].

The chances of false negativity and false positivity are not uncommon like other antigen-antibody-dependent reactions. In early phase of acute HCV infection, there is a window period in which the antibodies have not yet reached the detectable level by ELISA, and hence, the ELISA tests are falsely negative despite the viremia. False positive ELISA tests are also not uncommon $[25,26]$. False positive ELISA for anti-HCV can be seen in patients who have cleared the virus after acute infection or by therapy and as such may be positive on ELISA which may indicate past infection [27].

In high-risk populations, when there is clinical suspicion of HCV infection, positive ELISA results confirm the exposure to HCV. A qualitative study of HCV RNA should be performed to distinguish individuals with chronic infection from those who have eliminated the HCV spontaneously [28].

To evaluate which factor leads to this increased prevalence of HCV infection in hemophilic patients, we studied hemophilia A patients and use logistic regression analysis. We did not find any independent risk factor for hepatitis $\mathrm{C}$ infection and it seems that multitransfusion is the most important risk factor in this regard. Our results were similar to the results of Mojtabavi et al., in Isfahan, and some other studies in Iran and other countries [29]. While in Jang et al. study, there was a significant association of age with anti-HCV seropositivity by logistic regression analysis (odds ratio/95\% confidence interval [OR/CI]: 1.12/1.07-1.18, $\mathrm{p}<0.001$ ) [12].

In the present study, age at diagnosis of hemophilia showed an effect on number of years to get HCV infection in hemophilia A with a statistically significant difference $(\mathrm{p}=0.024)$. This means that the younger the patient the highest the possibility to get HCV infection compared to late age at diagnosis when holding the effect of treatment type constant; this could be attributed to the fact that as the patient diagnosed younger, he gets the highest chance to use more multiple transfusion during his life span and more chance to get HCV infection.

The present study showed a statistically significant difference in median current age between hemophilia A and B with $\mathrm{p}=0.0203$, but the prevalence of $\mathrm{HCV}$ infection was not statistically associated with 
Table 7: Association between diagnosis before or after 1996 and type of treatment received in HCV-positive cases among patients with hemophilia A and B

\begin{tabular}{llllll}
\hline Variable & \multicolumn{2}{l}{ Blood products and factors n (\%) } & Factors only n (\%) & p & \\
\hline $\begin{array}{l}\text { Hemophilia A } \\
\text { After 1996 }\end{array}$ & 5 & 11.90 & 27 & 47.37 & $0.0002^{* *}$ \\
$\quad$ Before 1996 & 37 & 88.10 & 30 & 52.63 & -0.374743 \\
Hemophilia B & & & & & \\
After 1996 & 0 & 0 & 4 & 17.39 & 1 \\
Before 1996 & 4 & 100 & 19 & 82.61 & -0.190347 \\
\hline
\end{tabular}

**Highly significant difference. HCV: Hepatitis C virus

the severity of factor VIII deficiency. Similar results were found in a study done by Jang et al. [12]. Antibody to HCV was discovered in late 1987 [9]. In Iraq, viral hepatitis prevention and control program were started during early seventies and screening blood donors for HCV were introduced in Iraq, in 1996 [10].

The present study showed that $32(32.32 \%)$ cases of hemophilia A had acquired HCV infection after 1996, and there was a statistically significant association with treatment by Factor VIII only rather than combination of factor and whole blood transfusion. Hence, in spite of screening method for HCV in blood banks, still there is a risk of getting infection during transfusion methods from paramedics or equipment. We recommend implementing blood safety strategies, donor selection, and quality assured screening of all donated blood and blood components as well as strengthening of infection control precautions in health-care centers and community settings to prevent viral hepatitis infection.

\section{CONCLUSION}

In this study, the prevalence of HCV in patients with inherited bleeding disorder was $13.2 \%$. It was found that multitransfusion is the only predictor for HCV infection in this group of patients. Anti-HCV antibody positivity was associated with the age at diagnosis of hemophilia, type of treatment, and presence of inhibitory antibodies but not with the type of hemophilia nor the severity of the disease.

\section{ACKNOWLEDGMENTS}

We acknowledge the paramedical staff in the hemophilia unit of Medical City for their help in collecting the data and appreciate the work of Hayder Adnan Fawzi in preparing the statistical analysis.

\section{AUTHORS' CONTRIBUTION}

Concept, collection of data, and writing the article - Manal Khudder Abdul Razak.

\section{CONFLICTS OF INTEREST}

The author declares that there are no conflicts of interest.

\section{REFERENCES}

1. World Health Organization. Hepatitis C. WHO Fact Sheets No 164; 9 April 2014. Available from: http://www.searo.who.int/thailand/ factsheets/fs0018/en/. [Last accessed on $2017 \mathrm{Feb} 26]$.

2. Ringelhan M, McKeating JA, Protzer U. Viral hepatitis and liver cancer. Philos Trans R Soc Lond B Biol Sci 2017;372:20160274.

3. Aruda V, High KA. Acute viral hepatitis. In: Longo DL, Fauci AS, Kasper DL, Hauser SL, Jameson JL, Loscalzo J, editors. Harrison's Principles of Internal Medicine. $17^{\text {th }}$ ed. New York: McGraw-Hill; 2012.

4. Nassiri TM, Lak M, Karimi K, Managhchi M, Samimi-Rad K, Abdollahi A. Seroprevalence of human immunodeficiency virus (HIV) and hepatitis $\mathrm{C}$ infection in hemophilic patients in Iran. Iran J Pathol 2008;3:119-24.

5. O'Leary JG, Davis GL. Hepatitis C. In: Feldman M, Friedman LS, Brandt LJ, editors. Sleisenger and Fordtran's. Gastrointestinal and Liver Disease. 10 $10^{\text {th }}$ ed. Philadelphia, PA: Saunders Elsevier; 2010. p. 1313-35.

6. Desai NA, Kotak KP, Patel SS. Investigation of epidemiology and etiology of liver diseases and characterization of its association with various factors. Asian J Pharm Clin Res 2015;8:346-9.

7. Alavian SM, Tabatabaei SV, Keshvari M, Behnava B, Miri SM, Elizee PK, et al. Peginterferon alpha-2a and ribavirin treatment of patients with haemophilia and hepatitis $\mathrm{C}$ virus infection: A singlecentre study of 367 cases. Liver Int 2010;30:1173-80.

8. World Federation of Hemophilia. Severity of Hemophilia A. Hemophilia News Today; 2012.

9. Sharifi-Mood B, Eshghi P, Sanei-Moghaddam E, Hashemi M. Hepatitis B and C virus infections in patients with hemophilia in Zahedan, Southeast Iran. Saudi Med J 2007;28:1516-9.

10. Zahedi MJ, Darviesh MS. Assessment of prevalence of hepatitis B and $\mathrm{C}$ in hemophilic patients in Kerman in 1383. J Kerman Univ Med Sci 2008;3:131-5.

11. Yazdani MR, Kassaian N, Ataei B, Nokhodian Z, Adibi P. Hepatitis C virus infection in patients with hemophilia in Isfahan, Iran. Int J Prev Med 2012;3:S89-93.

12. Jang TY, Lin PC, Huang CI, Liao YM, Yeh ML, Zeng YS, et al. Seroprevalence and clinical characteristics of viral hepatitis in transfusion-dependent thalassemia and hemophilia patients. PLoS One 2017; 12:e0178883.

13. Naghmi A, Tahira Z, Khalid H, Lubna N. Seroprevalence anti HCV antibodies, HCV-RNA and its genotypes among patients of hemophilia, at hemophilia treatment centre Pakistan institute of medical sciences, Islamabad. Int J 2009;7:84-7.

14. Waheed Y, Shafi T, Safi SZ, Qadri I. Hepatitis C virus in Pakistan: A systematic review of prevalence, genotypes and risk factors. World J Gastroenterol 2009; 15:5647-53.

15. Mohamoud YA, Riome S, Abu-Raddad LJ. Epidemiology of hepatitis $\mathrm{C}$ virus in the Arabian Gulf countries: Systematic review and metaanalysis of prevalence. Int J Infect Dis 2016;46:116-25.

16. Rikabi A, Bener A, Al-Marri A, Al-Thani S. Hepatitis B and C viral infections in chronic liver disease: A population based study in Qatar. East Mediterr Health J 2009;15:778-84.

17. Mohamoud YA, Mumtaz GR, Riome S, Miller D, Abu-Raddad LJ. The epidemiology of hepatitis $C$ virus in Egypt: A systematic review and data synthesis. BMC Infect Dis 2013;13:288

18. Biswas A, Sarkar K, Firdaus R, Saha K, Gupta D, Ghosh M, et al. Prevalence of anti-HCV, HBsAg, HIV among multi-transfused thalassemic individuals and their socio-economic background in Eastern India. Asian J Pharm Clin Res 2016;9:314-8.

19. Mohd Hanafiah K, Groeger J, Flaxman AD, Wiersma ST. Global epidemiology of hepatitis $\mathrm{C}$ virus infection: New estimates of age-specific antibody to HCV seroprevalence. Hepatology 2013;57:1333-42.

20. Tarky MA, Akram W, Al-Naaimi S, Ali O. Epidemiology of viral hepatitis B and C in Iraq: A national survey 2005-2006. Zanco J Med Sci 2013;17:370-80.

21. World Health Organization. Hepatitis C. WHO Fact Sheets. Geneva; 2000. Available from: https://www.who.int/csr/resources/publications/ hepatitis/en/. [Last accessed on 2016 Aug 20].

22. Fadlalla FA, Mohamoud YA, Mumtaz GR, Abu-Raddad LJ. The epidemiology of hepatitis $\mathrm{C}$ virus in the Maghreb region: Systematic review and meta-analyses. PLoS One 2015;10:e0121873.

23. Ataallah TM, Hanan KA, Maysoun KS, Sadoon AA. Prevalence of hepatitis $\mathrm{B}$ and $\mathrm{C}$ among blood donors attending the national blood transfusion center in Baghdad, Iraq from 2006-2009. Saudi Med J 2011;32:1046-50.

24. Tashkandy MA, Khodari YA, Ibrahim AM, Dhafar KO, Gazzaz ZJ, Azab BA, et al. Evaluation of the available anti-HCV antibody detection tests and RT-PCR assay in the diagnosis of hepatitis $\mathrm{C}$ virus 
infection. Saudi J Kidney Dis Transpl 2007;18:523-31.

25. Quiroga JA, Llorente S, Castillo I, Rodríguez-Iñigo E, Pardo M, Carreño V, et al. Cellular immune responses associated with occult hepatitis C virus infection of the liver. J Virol 2006;80:10972-9.

26. Lee YJ, Chang CT, Wu MS. Acute hepatitis C infection without anti$\mathrm{HCV}$ antibody in chronic hemodialysis patient. Chang Gung Med J 2006;29 Suppl 4:35-8.

27. Gupta E, Bajpai M, Choudhary A. Hepatitis C virus: Screening, diagnosis, and interpretation of laboratory assays. Asian J Transfus Sci 2014;8:19-25.

28. Dhawan VK. Hepatitis C Clinical Presentation. Medscape; 2018. Available from: https://www.emedicine.medscape.com/article/177792clinical. [Last accessed on 2016 Sep 10].

29. Mojtabavi NM, Derakhshan F, Hourfar H, Derakhshan R, Rajab FM. Analysis of the related factors in hepatitis $\mathrm{C}$ virus infection among hemophilic patients in Isfahan, Iran. Hepat Mon 2007;7:59-62. 